\title{
Gilân Sorunu ve Osmanlı-Safevi Devletleri Arasındaki Yazışmalar*
}

\author{
The Ghilan Question and the Correspondences Between the \\ Ottoman and Safavid States
}

\section{Cihat AYDOĞMUŞOĞLU **}

$\ddot{O} z$

Biz bu çalışmada, Osmanlı Devleti ile Safevi Devleti'ni bir süre meşgul eden fakat savaşla veya herhangi bir askeri harekâtla sonuçlanmayan, iki tarafin da sağduyulu ve savaştan kaçınacak şekilde hareket etmesi neticesinde ve de Gilân Hanının vefatı ile kendiliğinden son bulan Gilân Sorunu'nu, karşıllılı gönderilen mektupları da ortaya koyarak anlatmaya çalışacă̆ız.

Anahtar Kelimeler: Gilân, Ahmet Han, Şah Abbas, Osmanll-Safevi Devleti

\section{Abstract}

In this study, we are trying to touch upon the Ghilan question which occupied an important place in the Ottoman and Safavid states' history in the last decade of the 16th century. This problem, with the contribution of bilateral lenient policies and the sudden death of Khan of Ghilan, ended without any serious complication. We have also stidied the official correspondences between the Ottoman and Safavid states.

Key Words: Ghilan, Ahmad Khan, Shah Abbas, Ottoman and Safavid States

* Bu makale, Cihat Aydoğmuşoğlu, Şah Abbas ve Zamanı, Ankara Üniversitesi Sosyal Bilimler Enstitüsü Basılmamış Doktora Tezi, (Ankara 2011), s.78-90 arasında yer alan bölümden üretilmiştir.

** Araş. Gör. Dr., Ankara Üniversitesi, Dil ve Tarih-Coğrafya Fakültesi, Tarih Bölümü, aydogmusoglu@ankara.edu.tr 
Gilân, Hazar Denizi'nin güneyinde ve Elburz Dağları'nın kuzeyinde, merkez şehri Reşt olan İran'ın bir eyaletidir. Bu eyalet, genelde dağlar ve ormanlardan oluşan bir bölge idi. Safeviler zamanında eyalet iki kısımdan oluşmaktaydı. Doğu kısmının merkezi, Şah İsmail'in Safevi Devleti'ni kurmadan önce bir süre saklandığ Lahican; batı kısmının merkezi ise Reşt idi. Bu durum Şah Abbas'ın Gilân'1 tamamen fethetmesinden sonra değişmiştir. Reşt, Şah Abbas zamanında tüm Gilân Eyaleti'nin idare merkezi olmuştur. ${ }^{1}$ Gilân Sorunu ise Gilân Hâkimi Ahmet Han'ın Osmanlı Devleti'ne sığınması ile ortaya çıkan diplomatik bir olaydır.

Gilân, aynı zamanda Sünnîlerin yaşadığı bir bölge idi. Osmanlı Devleti de politikası gereği İran'ın Sünnî bölgeleriyle devamlı temas halindeydi. Doğal olarak Gilân'ın Sünnî halkı, Osmanlıların Safevilerle giriştikleri mücadelelerde Osmanlı Devleti'nin yanında yer alıyordu. Fakat 1590 yılında Osmanlı Devleti ile Safevi Devleti arasında sulh antlaşması yapılınca Osmanlıların İran'ın dâhilindeki yandaşları Safevilere karşı güvencesiz kalmıştı. ${ }^{2} \mathrm{Bu}$ doğrultuda Gilân Hâkimi Ahmet Han da desteksiz kalmıştı. Gilân eyaletinde Sünnî ahali olmasının ve Gilân hâkiminin Osmanlı Devleti ile temas halinde olmasının yanında bu bölge aynı zamanda Osmanlı ticaret kervanlarının gidip geldiği bir bölge olup, İran'ın da en zengin ipekçilik eyaletlerinden biri idi. Yine Safevi başkenti Kazvin'e yakınlı̆̆ sebebiyle stratejik açıdan da önemli bir eyalet idi.

Ahmet Han (d.1535/1536), Gilân'1n mahalli emirlerinden Sultan Hasan-1 Karkiya'nın oğlu idi. Karkiya sülalesi, kendi soyunu Şiilerin Dördüncü İmamı Zeynelabidin'e bağliyordu. Böylece Ahmet Han ve soyu "Seyyid" sayılıyorlardı. Zaten Şah İsmail, Ak Koyunlu takibinden kaçıp Lahican'a sığındığında Ahmet Han'ın ataları tarafından himaye edilmişti. Ahmet Han, babas1 H.943 (M.1536-1537) yılında vefat edince, daha bir yaşında iken Şah Tahmasp tarafindan Gilân'ın merkezi Lahican olan doğu tarafina hâkim tayin edilmişti. ${ }^{3}$ Fakat büyüyüp idareyi eline tam olarak aldıktan bir müddet sonra Gilân'ın batısını da hâkimiyeti altına alarak, eyaletin tamamına hükmetmeye başladı. Şah Tahmasp'ın hükümdarlığı süresince çeşitli gâileler çıkarmış olan Ahmet Han, H.975 (M.1567/1568) y1lından itibaren on y1lını hapishanede (Kahkaha ve İstahr [Şiraz] kalelerinde) geçirmiş, bu yüzden de

Cl. Huart, "Gilân”, İA, İstanbul, 1945, c. 4, s. 782.

Abdullah Gündoğdu, "Osmanlı Diplomasisinde Örnek Bir Olay: Gilân Sorunu (15911594)", KÖK Araştırmalar, Osmanlı Özel Sayıs1, 2000, s. 27. Bu makalemizde, A. Gündoğdu'nun zikredilen çalışmasına ek olarak, Safevi ve Osmanlı devletleri arasındaki yazışmalar ile Ahmet Han'ın İstanbul'daki ölümü konularına değinmeye çalıştık.

3 Meryem Nejad Ekberî Mihriban, Şah Abbas-ı Kebir, Şirket-i Mütâlaât ve Neşr-i Kitâb-1 Parsa, Tahran, 1387, s. 57. 
Safevilere düşman olmuştu. ${ }^{4}$ Zaten Safevi hükümetinin gözü de zaman zaman Safevi Devleti'ne [Şah'a] karşı Özbeklerle temas halinde olan ve gün geçtikçe bölgesinde güçlenen Ahmet Hanın üzerindeydi.

Şah Tahmasp'ın vefatından sonra Şah Muhammed Hüdabende'nin cülusu (1578) zamanında akrabası olan Şah'ın zevcesinin [Şah Abbas'ın annesi olan Mehd-i Ulya] delâletiyle serbest bırakılan Ahmet Han, tekrar Gilân Hâkimi yapılmıştır. Hatta Şah Muhammed Hüdabende, kendi kız kardeşi Meryem Sultan Hanım'1 (Şah Tahmasp'ın kızı) ona vermiştir. ${ }^{5}$ Ahmet Han, böylece Şah Muhammed zamanında Gilân'ın mutlak hâkimi olmuştu.

Gilân Hâkimi Ahmet Han, 1590 y1lında imzalanan Osmanl1-Safevi barışından sonra ise Şah'ın muhaliflerine sığınma hakkı vererek ve suçluların iadesini içeren ricaları reddederek açık bir şekilde Şah Abbas'a karşı meydan okumaktaydı. ${ }^{6}$ Ayrica Ahmet Han'ın H. 997 (M. 1588/1589 yılinda vezâretten azlettiği Hoca Mesih de Kazvin'e giderek Şah'1 Gilân'1n fethi için teşvik ediyordu. Zaten Kızılbaş beylerinin nüfuzunu kırmış olan Şah Abbas da bölgelerinde bağımsız gibi hareket eden hâkimleri itaat altına alıp, memlekette otoriteyi tesis etmek istiyordu. Bu yüzden Şah Abbas'ın Osmanlı Devleti ile yaptığı sulh antlaşmasından sonra üzerine geleceğini iyi bilen Ahmet Han, önce bir elçisini İstanbul'a göndermiş ve Padişah’tan yardım istemiştir.

Ahmet Han, Osmanlı Padişahı'na gönderdiği mektuplarında özetle şöyle diyordu: “Eğer siz, Hazar Denizi'nden gemilerle Gilân'a gelirseniz, hiç zahmet etmeden tüm Gilân'l alabilirsiniz. Ben de size yardım edebilirim. Bu düzenle Iran'ı da fethedebilirsiniz. "7

Gilân bölgesi başkent Kazvin'e yakın olduğundan Osmanlıların buraya yerleşmeleri ciddi bir tehdit oluşturabilecekti. Bundan endişe eden Şah Abbas, yaşanan bu gelişmeler üzerine Osmanlı Devletine karşı tam bir diplomatik taarruz başlattı. ${ }^{8}$ Buna karşılık Ahmet Han'ın elçisi Hüsâmeddin Tâcir [Lenkerudî] de Eylül 1591'de İstanbul'a gelmiştir. Ahmet Han, elçisi vasitasıla "hükm itdüğ̈ memleketinün nısf-l güzidesini" Osmanlı

4 A. Gündoğdu, a. g. m., s. 27.

5 Z. Sabityan, Esnâd ve Nâmehâ-yı Târihi Devre-i Safeviye, Be Sermaye-i Kitabhâne-i İbn-i Sina, Tahran, 1343, s. 279.

6 Audrey Burton, The Bukharans: A Dynastic, Diplomatic And Commercial History (15501702), Curzon Press, Great Britain, 1997, s. 69.

7 Rıza Pazuki, Târih-i İan (Ez Moğol Tâ Afşâriyye), Şirket-i Çaphâne-i Ferheng, Tahran, 1317, s. 314

8 A. Gündoğdu, a.g.m., s. 28. 
Padişahı'na bağışlıyor ${ }^{9}$, geri kalan kısmı için de Padişahtan kendi ve evlatları adına menşûr talep ediyordu. ${ }^{10}$ Böylece Ahmet Han, iktidarını kurtarmayı planlamıştı. Zira Şah Abbas'ın gözünün Gilân'da olduğunu çok iyi biliyordu.

Ahmet Han, ayrica Osmanlı Devleti'ne Şirvan üzerinden deniz yoluyla Lahican'a asker gönderirlerse kaleyi teslim edebileceğini söylüyordu. ${ }^{11}$ Fakat Safevilere karşı barışı korumaya kararlı olan Osmanlı devlet ricali ${ }^{12}$, Ahmet Han'ın göndermiş olduğu mektuplara itibar etmeyip, İran Şah'1 ile ihtilaf çıkmaması yönünde karar alıp, sulhu bozmadılar ve Ahmet Han'ın elçisini Divan'a kabul etmeyip geri gönderdiler. ${ }^{13}$ Zaten Şah Abbas da Ahmet Han olayında Osmanlı Devleti ile diplomatik yazışmalar yapmışsa da hiçbir zaman -doğudaki Özbek tehdidi bitmediğinden- sulhu bozmak niyetinde olmamıştı.

H. 1000 (M.1591/1592) tarihinde çıkan bir olay, Şah Abbas ile Ahmet Han'ın arasını iyice açmıştır. Şah Abbas, kendi oğlu Safi Mirza'yı Ahmet Han'ın küçük kızıyla nişanlamak istiyordu. Bu sırada Safi Mirza 4 yaşında, Ahmet Han'ın kızı ise 5 yaşında idi. Ahmet Han, "Şah Abbas Padişah" diye başladığı mektubunda oğlu Sultan Hasan'ın vefatıyla bir tek bu kızının kaldığını, bu sebeple ona çok bağlandığını bildirmekte ve Şah Abbas'tan affını rica etmekteydi. ${ }^{14}$ Fakat bu nişanın olmasında 1srarcı olan Şah Abbas, müneccimi Molla Celal'i aracı olarak tekrar Ahmet Han'a yolladı (22 Mart 1591). ${ }^{15}$ Molla Celal ile görüştükten sonra Şah'ın kararlı tutumunu anlayan Ahmet Han, nişana razı olmak zorunda kalmıştır.

Yukarıdaki olay dışında Şah ile Ahmet Han'ın arasını açan bir diğer olay da Ahmet Han'a sığınan ümeralar sorunudur. Şah Abbas'ın babasının ümerası ve bazı asi Kızılbaş reisleri Ahmet Han'a sı̆̆ınmıştı. Bunun üzerine Han'a haber gönderen Şah Abbas, babasının ümerasının ve asi Kızılbaş

9 A. Gündoğdu, a.g.m., s. 28.

10 Selânikî Mustafa Efendi, Tarih-i Selânikî, Haz: Mehmet İpşirli, TTK, Ankara, 1999, c. I, s. 255.

11 İskender Bey Türkmen, Târih-i Âlem Âra-yi Abbasi, Haz. İrec Afşar, Müessese-i İntişârât-1 Emîr Kebîr, Tahran, 1387, c. I, s. 449.

12 Osmanlı devlet ricali, Sadrazam Ferhat Paşa'nın evinde toplanmış ve şöyle karar vermiştir: "Şah Abbas, kardeşinin oğlunu İstanbul'a göndermiş ve itaat üzere olduğunu belli etmiştir. Tekrardan fitneye sebep olmaya gerek yoktur. Gilân elçisi Hüsâmeddin'e icazet verilsin ve Divân'a gelmeden Üsküdar'a geçirilsin.” Bkz. Selânikî Mustafa Efendi, a. g. e., s. 256

13 A. Gündoğdu, a.g.m., s. 28

14 Menuçehr Pârsadûst, Şah Abbas-ı Evvel, Şirket-i Sihâmi-i İntişar, Tahran, 1388, c. I, s. 147.

15 Molla Celâleddin, Rûzname-i Molla Celâl, Haz. Seyfullah Vahidniya, İntişârât-1 Vahid, Tahran, 1366, s. 108. 
reislerinin iadesini istemiştir. İskender Bey Münşî de Şah Abbas'ın Ahmet Han'ın asi emirleri himaye etmesinden dolayı Han'a kırgın olduğunu yazmaktadır. ${ }^{16}$ Bunun üzerine Ahmet Han, Şah'tan kaçan mülteci beyleri bağışlanmaları dileğiyle Kazvin'e gönderdi. Fakat bu beyler Kazvin'e girmeden katledilip, cesetleri teşhir edildi. Bunun üzerine Gilân Hâkimi Ahmet Han, Osmanlı Sultanına dostluk ve itaat arzına meylettiği gibi diğer taraftan Moskova'ya Rus Çarına da bir heyet gönderdi. ${ }^{17} \mathrm{Bu}$ yaşanan gelişmelerin doğal bir sonucu olarak uzun süre geçmeden Şah ile Han arasında huzursuzluk baş göstermiş ve savaş kaçınılmaz olmuştur. Son olarak Şah Abbas, Ahmet Han'ın Osmanlı Padişahına memleketinin yarısını hibe ettiğini bildiren mektubundan haberdar olmuş ve buna çok öfkelenmişti. Ayrica Gilân Hâkimi'nin İstanbul'a elçi gönderilmesinden ve diğer işlerin hiç birisinden haberinin olmadığını söyleyip kendisine yapılan tüm isnatları reddetmesi, fakat istihbarat ağ̀ güçlü olan Şah'ın ad1 geçen elçi Hoca Hüsameddin'in, Han Ahmet'in arîzasını Osmanlı hükümdarına götürdügünü öğrenmesi bardağı taşıran son damla olmuştur. Sonunda öfkelenen Şah Abbas, Ahmet Han'ın ailesinin ortadan kaldırılmasina karar verdi. ${ }^{18}$ Bunun üzerine, Gilân'ın Safevi mülkü olduğunu belirten bir mektubunu ${ }^{19}$ elçisi Bayezid Ağa ile İstanbul'a gönderen Şah Abbas, ardından 1592 baharında, Gilân Han'1 Ahmet Han'a haddini bildirmek ve bölgeyi hâkimiyeti altına almak maksadıyla gözde komutanlarından Vekil-i Saltanat Karamanlu Ferhat Han ve kardeşi Zülfikar Han kumandasındaki Safevi kuvvetlerini Gilân'1 fethe göndermiştir. Gilân hükümdarı Ahmet Han, başkumandanı Emir Abbas'ın kumandasındaki 20.000 kişilik süvari ve piyade askerinin, tüfenkçilerle donatılmış Safevi ordusu karşısında hezimete uğrayıp, Emir Abbas'ın muharebeden çekildiğini haber alınca bir gemi ile Osmanlı hâkimiyetindeki Şirvan'a kaçmıştır. ${ }^{20}$ Ferhat Han'ın Ahmet Han'ı kaçmaya

16 İskender Bey Münşî, Tarih-i Âlem Ara'-i Abbasi, Çev: Ali Genceli, TTK, İstanbul, 1945, c.II, Kisim I, s. 138.

17 Hafez F. Farmayan, The Beginnings Of Modernization In Iran: The Policies And Reforms Of Shah Abbas I (1587-1629), Middle East Center University Of Utah, Salt Lake City, Utah, 1969, s. 13.

18 İskender Bey Münşî, a.g.e., s. 139.

19 Bu mektup İstanbul'a H.1000 y1lı Recep ayı ortalarında (M. Nisan 1592) ulaşmıştı. Bu mektubunda Şah, şöyle diyordu: "Gilân Hâkimi Han Ahmed sâbıka Âsitâne-i sa'âdete [İstanbul'a] ilçisin gönderüp ve memleket defterin îsâl idüp [ulaştırıp], bağışladuğ mülkde kendünün medhali [karışma yetkisi] yokdur. Eben an ceddin [atadan beri] mülk-i mevrusumuz [miras kalmış toprak] olduğı ma'lûm-ı âlemiyândur [tüm insanlık tarafindan bilinmektedir]. Ol takdîrce kimün mülkin hîbe ider." Bkz. Selânikî Mustafa Efendi, a. g.e., s.267

20 Remzi Kılıç, XVI. ve XVII. Yüzyıllarda Osmanlı-İran Siyasi Antlaşmaları, Tez Yayınları, İstanbul, 2001, s. 137. 
zorlamasından sonra Şah Abbas, bizzat Gilân'a yönelip, bölgeyi ilhak etmiş, Ahmet Han'ın şehzadelerini bağışlamış ${ }^{21}$ ve Gilân hükümetini Mehdi Han-1 Şamlu'ya vermiştir. Bu sırada Gilân emirleri de Şah'ın huzuruna gelip bağll1ıklarını bildirmişlerdir. ${ }^{22}$ Şah Abbas, Gilân ve Lahican'da birkaç idarî atama yaptıktan sonra Horasan'da Özbeklere karşı harekete geçmek için bölgeden ayrılmıştır. Fakat kısa bir süre sonra 1593 yılında Gilân'da Biye Pes sipehsalarlığı kendisine verilen Şah Melek adında biri isyan çıkarınca, Şah Abbas, Ferhat Han'1 Allah Kulu Bey ve Korucubaşı Hüseyin Bey Şamlu ile birlikte âsilerin cezalandırılması için tekrar Gilân'a göndermiştir. Neticede kısa zamanda Şah Melek öldürülmüş ve Gilân halkı onun zulmünden kurtulmuştur. Daha sonra Şah, Gilân Hâkimliğini Rumlu Ferhat Han'a vermiştir. ${ }^{23}$ Bir müddet sonra Gilân hâkimliği tekrar el değiştirecek, Ferhat Han Şiraz Hâkimliği'ne, Rumlu Derviş Mehmet Han da Gilân Hâkimliği'ne atanacaktır. ${ }^{24}$

Şah Abbas'ın Gilân'ı fethi ile Deylem ${ }^{25}$ coğrafyası da Safevi Devleti'ne ilhak edilerek, Gilân'a tayin edilen valiler tarafından idare edilmeye başlanmıştır. ${ }^{26}$

Safevilerden kaçan Ahmet Han ise Osmanlıların Şirvan Muhafızı Hasan Paşa'ya sığınmıştı. Hasan Paşa bu durum üzerine İstanbul'a bir mektup göndermiş ve ne yapması gerektiğini sormuştur. Ona gönderilen cevapta Ahmet Han'ın Şirvan'da bir yerde iskân edilmesi ve masraflarının da Şirvan hazinesinden karşılanması emredilmiştir. ${ }^{27}$ Ahmet Han'ın Osmanlılara sığınmasından sonra iki devlet arasında yazışmalar olmuştur. Şah Abbas, Ahmet Han'ın Osmanlı Devleti'ne ilticası üzerine Eşikağası Seydi Bey'i İstanbul'a elçi olarak bir mektupla göndermiştir. Bu mektubunda, Gilân ülkesinin öteden beri Safevilerin tasarrufunda bulunduğunu belirten Şah Abbas, Ahmet Han'ın esasen Safevilere tâbi olduğunu fakat itaatten çıkıp halka zulüm yaptı̆̆ 1 için üzerine gidilip, Gilân topraklarının Safevi ülkesine katılmış olduğunu belirtmiştir. Ayrıca Ahmet Han'ın Osmanlı Devleti'ne sığınmasının sulha aykırı olduğunu söyleyen Şah Abbas, iki taraf arasında fitne çıkarması ihtimali olduğundan Ahmet Han'ın tutuklanabileceğini

21 Şah Abbas, Ahmet Han'ın kızını ise oğlunun nişanlısı olması sebebiyle beraberinde Kazvin'e götürmüştür. Bkz. M. Pârsadûst, a.g.e., s. 153.

22 İskender Bey Türkmen, a.g.e., s. 451.

23 R. Pazuki, a.g.e., s. 314.

24 İskender Bey Münşî, a.g.e., s. 234.

25 İran'ın kuzeyinde bulunan Gilân eyaletinin bir kısmını teşkil eden dağlık araziye verilen addir.

26 Ahmed Ateş, "Deylem", $\dot{I} A$, İstanbul, 1993, c. 3, s. 57.

27 Selânikî Mustafa Efendi, a.g.e., s. 271. 
yazmıștır. ${ }^{28}$ Bunun üzerine Osmanlı Sultan'1 III. Murat, Haziran/Temmuz 1592'de Şah'a bir mektup yazıp, İstanbul Antlaşması'nda kararlaştırılan sınırların dışına çıkmayacaklarını, Ahmet Han'ın eskiden beri Osmanlılarla irtibat halinde olduğundan ilticasının sulha aykırı olmadığını, Gilân Hâkimi Ahmet Han'1 affetmesini, akrabalarına iyi davranılmasını ve görevini iade etmesini istemiştir. ${ }^{29}$ Şah, III. Murat'a verdiği cevapta onun geri dönmesine karşı olmadığını fakat görevini iade etmesinin mümkün olmadığını çünkü Gilân halkının ondan bıktığını dile getirmiștir. ${ }^{30}$ Şirvan'da [Şamahı] ikameti uzun sürmeyen Ahmet Han, muhtemelen İstanbul'a gelmesine izin çıkınca memleketini geri almak için Padişah'tan bizzat yardım istemek maksadıyla Şirvan'dan İstanbul'a gitti. 1592 yılının sonlarına doğru İstanbul'a ulaştı ve Osmanlı Padişahı III. Murat'a (1574-1595) sığındı. 13 Ocak 1593 tarihinde Divan'a ve huzura kabul edilen Ahmet Han, bir ay sonra Vezîr-i Âzam Sinan Paşa tarafından da kabul olunarak teselli edildiyse de umduğu alâkayı görememekten dolayı üzgün bir şekilde Meşhedeyn ${ }^{31}$ ziyareti için izin talep etmiştir. ${ }^{32}$

Şah Abbas'ın Hindistan'daki Babür İmparatorluğu hükümdarı Celaleddin Ekber Şah'a (1556-1605) yazdığ 1 ve kendi fetihlerini aynı zamanda da Gilân Hâkimi Ahmet Han'ın Osmanlılara sığınması olayını anlattığı mektubundan bahsettikten sonra Osmanlı Saray1 ile olan yazışmalarını ve olayın devamını anlatmak daha faydalı olacaktır. Şah Abbas, Ekber Şah'a gönderdiği mektubunda şöyle yazmaktadır:

"Bu Ahmet Han ki bizim ekmeğimizi yemiştir, bunun hakkını yerine getirmedi. Bizi sırtımızdan vurdu. Gilân halkına şiddet uyguladı. Bizim hükümetimizi yok etmeye kalktı. Biz, ona çok merhamet gösterdik. Ama o, bu merhametin cevabinı bizi yok etme planlarlyla verdi. Bizim sabrimızı ve yumuşak huyluluğumuzu başka türlü anladl. En kötüsü de başka bir ülkeye siğındı. Ayrıca sürekli Iran'ı ele geçirmek için planlar yapmaktadır. Gilân halkı iyi bir hâkime layıktır. Onun yeniden Gilân hâkimi olmasını istemiyorlar. Ĕger yeniden gelmek istiyorsa onu, tüm yaptıklarına ră̆men affederiz. Ama Gilân hâkimi olup-olmamasının kararını biz veririz." ${ }^{33}$ Şimdi Şah'ın Osmanlı sarayı ile olan yazışmalarına ve olayın gidişatına devam edebiliriz.

28 R. K1lıç, a.g.e., s. 137.

29 Feridun Bey, Мecmua-i Münşeat-i Feridun Bey, İstanbul, 1275, c. II, s. 254.

30 Z. Sabityan, a.g.e., s. 280.

31 Bağdat yakınlarında bulunan, Hz. Ali ile Hz. Hüseyin'in kabirlerinin bulunduğu ve Şiilerce kutsal sayılan bölgeye verilen isim.

32 Bekir Kütükoğlu, Osmanlı-Iran Siyasi Münasebetleri (1578-1612), İstanbul Fetih Cemiyeti Yayınları, İstanbul, 1993, s. 210.

33 Z. Sâbityan, a.g.e., s. 281. 
Şah Abbas, Osmanlı Sultan'1 III. Murat'1n hocası Sadeddin Efendi ${ }^{34}$ ve III. Murat'ın vezirleri ile Gilân sorunu sebebiyle mektuplaşmıştır. Bu mektuplarda Şah, Ahmet Han'ın art niyetli hareketini, kendine karşı isyan etmiş olduğunu belirtip, onun İstanbul'da yaşamasının iki devlet için de tehlikeli olduğunu söyleyerek, 1srarla Ahmet Han'ın iadesini talep etmiştir. Şah, Sadeddin Efendi'ye yazdığı mektubunda şöyle demekteydi: "Herkes biliyor ki Gilân Hâkimliği eski zamanlardan beri bizim uhdemizde idi. Onların Gilân'a hâkim olması benim sülalemin onayıyla gerçekleşmişti. Her zaman bir suçu olsa benim atalarm cezalandırlyordu. Ahmet Han, kendi halkr ve bizim memlekete hlyanet etmiştir. Kendi suçunu sizin devletinizle paylaşmak için size sığınmıştır. Bu konu bizim halkımızı ve devletimizi çok üzmektedir. Ben önceden de mektup gönderip, onu Iran'a iade etmenizi talep etmiştim. Bizim barış antlaşmamızda -eğer herhangi bir taraftan bir isyankâr diğer ülkeye siğınırsa kendi ülkesine teslim edilmek zorundadırmaddesi vardır. Ahmet Han, benim ülkemin vatandaşı olarak sizin ülkenize sığınmışıtır. Bu ülkenin yüce padişahı, o adamı kabul etmiştir. Bizim anlaşmamızda böyle bir madde yoktur. İran şehzadelerinden biri sizin ülkeye gelirse onu göndermek zorundasinız. Bu Müslüman dünyası için daha hayırlıdır. İki ülkenin Müslümanlarına bu daha hayırlıdır. Aksi ise zararlıdır. Bir câninin padişahın himayesinde olması câiz değildir. Bu konu bizi, iki ülkenin ilişkileri açısından meyus etmektedir. Bu, bizim hizmetlerimizi hiçe saymaktır. Benim Allah'ın adaletine güvenim vardır. Ben, iki ülke arasında imzalanan muahedeye aykır bir şey yapmadım. Müslümanların huzuru için elimden geleni yaptım ve yapacă̆ım. Ama bizim de sizden bir ricamız var. Ĕger iki ülkenin dostluğunu sağlamak istiyorsanız, Ahmet Han'in ülkenizde yaşamasina izin vermeyin." 35 Hoca Sadettin Efendi'nin Şah'a cevabı ise şöyleydi: "Bizim sarayımıza bir misafir sığınırsa ve bu kişi Seyyid olursa, bundan da öte bu kişi bir Müslüman ise şeriatımıza göre kabul ederiz. Mektubunuzda bizi, antlaşmaları bozmakla itham ediyorsunuz. Biz, antlaşmalarımızı hiçbir zaman bozmadık. Bize göre misafir, Tanrı'nın sevgilisidir. Misafiri evden çılkarmak bizim de sizin de dininize aykırıdır. Ahmet Han, Seyyid, şâir ve Tanrı'nın kuludur. Onun niyeti sizi rahatsiz etmek veya sizin mülkünüze taarruz etmek değildir. Ĕger bir yanlışlık olmuşsa geçmişte olmuştur. Şu anda o, kendini ülkesine bağgl

34 Hoca Sadeddin Efendi (1536-1599), Türk tarihçi, şeyhülislam ve müderris. Osmanlı Padişahı III. Murat'ın şehzadeliğinde hocalığını yapmıştır. Bu sebeple III. Murat'ın 1574 yılında tahta geçmesiyle Hâce-i Sultâni sıfatıyla devlet işlerinde etkili olmuştur. Şah Abbas ile de bazı siyasi ve içtimai konularda mektuplaşıp, aracılık yapmıştır. Aynı zamanda meşhur Tâcü't-Tevârih adlı Osmanlı Tarihi'nin yazarıdır.

35 Z. Sabityan, a.g.e., s. 282-284. 
olarak biliyor ve sizden af talep ediyor. Dinimizde de büyükler af ederler. Onun amacı sizin hükümetinizin sâyesinde yaşamaktır. Sizinle mücadele etmek gibi bir amacı yoktur. Ben, sizi İran Şah'l, şâir ve derviş ruhlu bir adam olarak biliyorum. Ama Ahmet Han'ın dönmesi kendi isteğine bağlıdır."

Şah Abbas'ın bu mektuba cevabı ise şöyledir: "Sen, bu adamın Ehl-i Beyt'e, Tanrı'ya saygll, Müslüman bir adam olduğunu söylüyorsun. Ama bir Müslüman kendi dininin şartlarına uymak zorundadır. İnsâni ve ahlaki konularda aykırı bir davranışı olursa cezalandırılması lazımdır. Ĕger insanlara zulüm edip, malların gasp ederse ve kendine meşru olmayan yollardan mal toplarsa hatta insanlarn namuslarına musallat olursa böyle bir insan Müslüman olamaz. Müslüman olsa bile yaptı̆̆ı suçlardan dolayı cezalandlrılması lazımdır. Eğer bir insan şeriata aykırı bir suç işlerse ilk defa ona nasihat etmek lâzım ki barışa uyalım. Ama nasihatin faydalı olmadı̆̆ zaman Allah'in emriyle onunla mukabele etmek lazımdir. Beytullah'a gidenlerin kalbi temiz ve şeytanın şerrinden uzak olması lazımdır. Hatta Hacca dahi gitse fakat kalbi temiz olmasa onun imanının değeri yoktur. Siz, Ahmet Han'l ne kadar da bana tarif etseniz o adam, bir Müslüman ülkede insanlartn namusuna taarruz etmiş, camileri yıkmış, suçsuz insanları öldürmüş ve sonra da birkaç ülkeye siğınmak istemiş ama o ülkeler bu adamın niyetini anlayıp kabul etmemişlerdi. Siz, mektubunuzda benden onu affetmemi istiyorsunuz. Ama kendi dinine ve inancına aykır işler yapan bir insanın cezası olmayacak mı? Acaba İslâm dininde suçlular için ceza yok mudur? O, Iran'a gelebilir. Fakat onun hakkındaki kararı biz vereceğiz. Bu konuda bizim israrımı onun Iran'a iade edilmesidir. Ahmet Han'in [Gilân] Hâkimliği konusunda ise - babası da Gilân Hâkimi idi- biz iyi biliyoruz ki suç işlemeseydi biz onun sülalesine -babası zamanında da- destek veriyorduk. Kurallara uysalardı hâlen Şah'ın himayesi altında idiler. Ama mesele, başka yerlere taarruz edip, kan dökme olunca ne ben, ne de benden önceki Şahlar buna rıza göstermiştir. Biz, iki ülkenin dostluğunu istiyoruz. Sizinle antlaşmamız var. Ahmet Han'ın Osmanlı Sarayı'nda olması sizin için de tehlikelidir. Çünkü o adamın niyeti kötüdür. Biz kendi isteğimizde ısrar etmekteyiz. Onun İran Şah'ına gönderilmesini talep ediyoruz. Bu, iki ülkenin dostluğu ve barışın devamı için daha faydalıdır."

Şah Abbas, ayrıca III. Murat'ın vezirlerine hitaben de bir mektup yazmıştır. Bu mektubunda Şah, özetle iki ülkenin ilişkilerinin gelişmesinin ve siyasi-ticari alanlarda ilerleme kaydedilmesinin Ahmet Han'in iade

36 Z. Sabityan, a.g.e., s. $284-287$.

37 Z. Sabityan, a.g.e., s. 287-293. 
edilmesine bağl1 olduğunu belirterek, vezirlerin Padişah ile konuşup bu engelin ortadan kalkması için aracı olmalarını istemiş ve kendi niyetinin iki ülke arasında dostluk ve barışın tesisi olduğunu söylemiştir. ${ }^{38}$

Sonunda, İstanbul'da istediklerini gerçekleştirebileceği bir ortamı bulamayan Ahmet Han, 1593 yılının Nisan ayı başlarında Osmanlı Devleti'nin izni ile Bağdat'a gitmiştir. ${ }^{39}$ Osmanlı Devleti, Ahmed Han'ın Bağdat'a gidişinden iki ay sonra Şah Abbas'a bir mektup göndererek, Ahmed Han'ın İran'a döndüğü takdirde hayatına dokunulmayacağ 1 hakkındaki Şah'ın vaadini hatırlatmıştır. Ayrıca Han'ın Kerbela ziyaretinden sonra İran'a döneceği ve iki devlet arasındaki muahedeye zarar gelmesi ihtimali olmadığı beyan edilmiştir. ${ }^{40}$

Irak'ta bir süre kalan Ahmet Han, emellerini gerçekleştirmek için başka bir destek ${ }^{41}$ bulmak ümidiyle daha rahat hareket edebileceği bir yere gitmek istemiş ve bu amaçla Şirvan'da bıraktığı ailesini bahane ederek Bağdat Muhafızı Vezir Müşîr Hızır Paşa'dan izin alarak Şirvan'a gitmek üzere yola çıkmıştır (Temmuz 1594). Fakat Gence'ye geldiğinde Özbek Han'1 II. Abdullah ile irtibat kurmak istediği anlaşılan Ahmet Han, Gence Beylerbeyi Mahmut Paşa tarafından hapse atılmıştır. ${ }^{42}$ Zira Osmanlı Devleti, Ahmet Han'ın rahat durmayarak Safevilerle yapılan barışa zarar getireceğinden endişe etmiştir.

Osmanlı Devleti, Ahmet Han'ın Seyyid ${ }^{43}$ olması dolayısıyla öldürülmesine razı değildi. Bunun üzerine önce Tokat'a, sonra da İstanbul Üsküdar'a yerleşmesine izin verilmiştir. Zira Osmanlı Devleti, Ahmet Han'ın İran'a karşı merkezde bulundurulması devlet siyasetine daha uygun bulmuştur. Çünkü lüzumu halinde kendisinden istifade olunması başkentte oturduğu takdirde daha kolay olacaktır. İstanbul'a yerleşmesinden sonra Ahmet Han'a Seyyid olduğu için bir hayli hürmet gösterilip, ödenek tahsis edilmiştir.

Z. Sabityan, a.g.e., s. 293-297.

Selânikî Mustafa Efendi, a.g.e., s. 311.

40 Halil Edhem, "Karkeyâiyye'den Han Ahmed'in İstanbul'a İlticası Hakkında Bir Vesika", Türk Tarih Encümeni Mecmuası, İstanbul, 1341, s.303.

${ }^{41} \mathrm{Bu}$ destek, Şah'ın doğudaki düşmanı olan ve Horasan'a akınlar yaparak Safevileri uğraştıran Özbeklerdir.

42 Selânikî Mustafa Efendi, a.g.e., s. 382.

43 Ahmet Han'ın soyu, İmam Ali neslinden Kârkeya bin Emîrkeya adında 14.yüzyılda Gilân'da hüküm süren bir zâta dayanıyordu. Bkz. İ. H. Uzunçarş1lı, "Osmanlı Devletine İltica Etmiş Olan Kârkeya Hânedanından Ahmed Han Nerede Vefat Etti?", Belleten, 28/109 (1964), TTK, Ankara, s. 73. 
Gilân Hâkimi Ahmet Han, H.1005 (M. 1596/1597) yılında 63 yaşında memleketinden uzakta İstanbul'da vefat etmiştir. ${ }^{44}$ Ahmet Han, fâzıl, şâir, çok zeki ve kurnaz bir kimse idi. ${ }^{45}$

Sonuç olarak; Gilân Hâkimi Ahmet Han'ın Osmanlı Devleti'ne sığınmasıyla başlayan kritik süreç, iki tarafın da sağduyulu davranışı ve aradaki sulhu bozacak hareketlerden kaçınmasıyla kendiliğinden ortadan kalkmıştır. Osmanlı Devleti, tekrar bir savaşa sebebiyet vermemesi için Ahmet Han'ın hareket alanını kısıtlarken, Safevi hükümdarı Şah Abbas da Özbek tehdidi ve dâhili işleri sebebiyle Gilân sorununu askeri boyutlara taşıyacak şekilde büyütmek istememiştir.

44 İskender Bey Türkmen, a.g.e., s. 529.

45 M. Mihriban, a.g.e., s. 60. 


\section{Kaynakça}

ATEŞ, Ahmet, “Deylem”, İA, İstanbul, 1993,c. 3, s.567-573.

BURTON, Audrey, The Bukharans: A Dynastic, Diplomatic And Commercial History (15501702), Curzon Press, Great Britain, 1997.

EDHEM, Halil, “Karkeyâiyye'den Han Ahmed'in İstanbul'a İlticası Hakkında Bir Vesika ”, Türk Tarih Encümeni Mecmuasl, İstanbul, 1341, s. 297-304.

FARMAYAN, Hafez F., The Beginnings Of Modernization In Iran: The Policies And Reforms Of Shah Abbas I (1587-1629), Middle East Center University Of Utah, Salt Lake City, Utah, 1969.

FERIDUN BEY, Mecmua-i Münşeat-i Feridun Bey, İstanbul, 1275, c. II.

GÜNDOĞDU, Abdullah, "Osmanlı Diplomasisinde Örnek Bir Olay: Gilân Sorunu (15911594)”, KÖK Araştırmalar, Osmanlı Özel Sayıs1, 2000, s. 25-30.

HUART, Cl., “Gilân”, İA, MEB, İstanbul, 1945, c.4, s. 782-783.

İSKENDER BEY MÜNŞ̂ি, Tarih-i Âlem Ara'-i Abbasi, Çev: Ali Genceli, TTK, İstanbul, 1945, c.II, K1sim I.

İSKENDER BEY TÜRKMEN, Târih-i Âlem Âra-yi Abbasi, Haz. İrec Afşar, Müessesi-i İntişârât-1 Emîr Kebîr, Tahran, 1387, c. I-II.

KILIÇ, Remzi, XVI. ve XVII. Yüzyıllarda Osmanlı-İran Siyasi Antlaşmaları, Tez Yayınları, İstanbul, 2001.

KÜTÜKOĞLU, Bekir, Osmanl-Iran Siyasi Münasebetleri (1578-1612), İstanbul Fetih Cemiyeti Yayınları, İstanbul, 1993.

MİHRIBBAN, M.N.E., Şah Abbas-ı Kebir, Şirket-i Mütâlaât ve Neşr-i Kitâb-1 Parsa, Tahran, 1387.

MOLLA CELÂLEDDİN, Rûznâme-i Molla Celâl, Haz. Seyfullah Vahidniya, İntişârât-1 Vahid, Tahran, 1366.

PÂRSADÛST, Menuçehr, Şah Abbas-ı Evvel, Şirket-i Sihâmi-i İntişar, Tahran 1388.

PÂZUKİ, Rıza, Târih-i İan (Ez Moğol Tâ Af̧̧âriyye), Şirket-i Çaphâne-i Ferheng, Tahran, 1317.

SÂBİTYAN, Z., Esnâd ve Nâmehâ-yı Târihi Devre-i Safeviye, Sermaye-i Kitabhâne-i İbn-i Sina, Tahran, 1343.

SELÂNIKÎ MUSTAFA EFENDİ, Tarih-i Selânikî, Haz: Mehmet İpşirli, TTK, Ankara, 1999, c. I.

UZUNÇARŞILI, İsmail Hakkı, "Osmanlı Devletine İltica Etmiş Olan Kârkeya Hânedanından Ahmed Han Nerede Vefat Etti?”, Belleten, 28/109 (1964), TTK, Ankara, s. 73-83. 